\title{
A Case of Second Branchial Cyst in Retropharyngeal Space, Appearing as Dyspnea and Dysphagia
}

\author{
Jung Hyeob Sohn ${ }^{1}$ and Kang Hyeon Kim ${ }^{2}$ \\ ${ }^{1}$ Department of Otorhinolaryngology-Head and Neck Surgery, Sanggye Paik Hospital, College of Medicine, Inje University, Seoul; and \\ ${ }^{2}$ Bundang Jesaeng Hospital, Seongnam, Korea
}

\section{호흡 곤란과 삼킴 곤란 증상을 보인 후인두의 제2 새기형 1예}

\author{
손 정 협 ${ }^{1}$ 김 강 현 ${ }^{2}$ \\ 인제대학교 의과대학 상계백병원 이비인후과학교실, ${ }^{1}{ }^{\text {분당제생병원 }}{ }^{2}$
}

\author{
Received April 2, 2016 \\ Revised May 12, 2016 \\ Accepted May 15, 2016 \\ Address for correspondence \\ Jung Hyeob Sohn, MD \\ Department of Otorhinolaryngology- \\ Head and Neck Surgery, \\ Sanggye Paik Hospital, \\ College of Medicine, Inje University, \\ 1342 Dongil-ro, Nowon-gu, \\ Seoul 01757, Korea \\ Tel +82-2-950-1104 \\ Fax +82-2-935-6220 \\ E-mail entsohn@gmail.com
}

The authors report the clinical features of a huge retropharyngeal second branchial cyst in a 53-year-old woman. The patient showed acute exacerbation of dyspnea and dysphagia. On endoscopic examination and computed tomography (CT), a cyst-like lesion narrowing the oropharynx was observed in the right retropharyngeal space. However, a retropharyngeal abscess was also suspected on some CT images. A cystic mass was found and removed completely via exploration by trans-oral approach. According to the literature review, a branchial cleft anomaly mimicking retropharyngeal abscess is very rare.

Korean J Otorhinolaryngol-Head Neck Surg 2016;59(8):628-32

Key Words Branchial cleft anomalies · Dysphagia - Dyspnea · Pharynx · Retropharyngeal abscess.

\section{서 론}

후인두의 낭종성 종양은 인두벽에 존재하는 부 침샘 조직 에서 기원하는 종양이나, 림프 조직의 낭성 변화, 새기형(branchial cleft anomaly), 신경성 종양, 표피성 봉입 낭종 등이 원 인이 되어 나타날 수 있다. ${ }^{1)}$ 새기형의 경우는 대부분 제 2 새기 형이고, 그 중에서 누공의 형성 없이 후인두 벽에 국한된 낭종 의 소견을 보이는 경우는 매우 드문 것으로 알려져 있다. 국 내에서는 두 명의 소아 환자에서 발생한 후인두의 낭종에서 제2 새기형이 진단된 증례가 보고된 바 있다.,3)

대부분의 새기형은 무증상이지만, 상피 하층에 존재하는 림프 조직으로 인해 상기도 감염 후 크기가 증가하면서 주위 조직을 누르게 될 경우 통증이나 국소적인 압박 증상을 느끼 게 될 수 있다. 따라서 후인두벽에 국한된 낭종의 형태를 보 이는 제 2 새기형은 주위 조직에 급성 염증이 동반되면서 병변 이 갑자기 커지고 인후통과 삼킴 곤란, 호흡 곤란 등의 증상
이 발생하는 경우, 초기에 이비인후과적 응급 질환인 후인두 농양으로 생각될 수 있으므로 감별이 필요하겠다.

저자들은 53세 여자 환자가 급성 상기도 감염 및 기도 폐색 증상으로 응급실을 통해 내원하여 후인두 농양의 가능성을 염두에 두고 치료하는 과정에서, 구강을 통한 완전 적출을 시 행하였고 병리 조직학적 검사를 통해 후인두에 발생한 제 2 새 기형으로 진단하였기에 문헌 고찰과 함께 보고하는 바이다.

\section{증 례}

53세 여자 환자가 2일 전부터 발생한 발열, 오한, 인후통과 함께 내원 당일 호흡 곤란을 호소하여 응급실을 내원하였다. 환자는 비흡연자로 최근 과음한 적은 없었다고 하였으며, 과 거력에서 타 병원에서 특발성 갑상선 기능 저하증으로 진단 받고 2년간 levothyroxine을 복용하였고, 잦은 편도염의 병 력은 없었다. 내원 당시 환자는 고형 음식을 삼키기 어렵다고 
하였으며, 고개를 우측으로 돌릴 때 호흡곤란이 더 심해진다 고 하였다. 70도 rigid endoscope을 이용한 인후두경 검사에 서, 우측 후인두 벽의 융기된 병변으로 인해 구인두부터 후두 개 입구까지 기도가 좁아져 있었고 양측 구개편도와 병변을 덮고 있는 구인두 점막은 정상 소견을 보이고 있었다(Fig. 1). 혈액검사에서 백혈구 수치가 13600(호중구 81.6\%)을 보이고, 적혈구 침강속도(erythrocyte sedimentation rate)가 $30, \mathrm{C}-$ 반응 단백질(C-reactive protein)이 2.78로 약간 증가된 것 외에는 특이 소견은 없었다. 응급실에서 시행한 경부 조영 컴

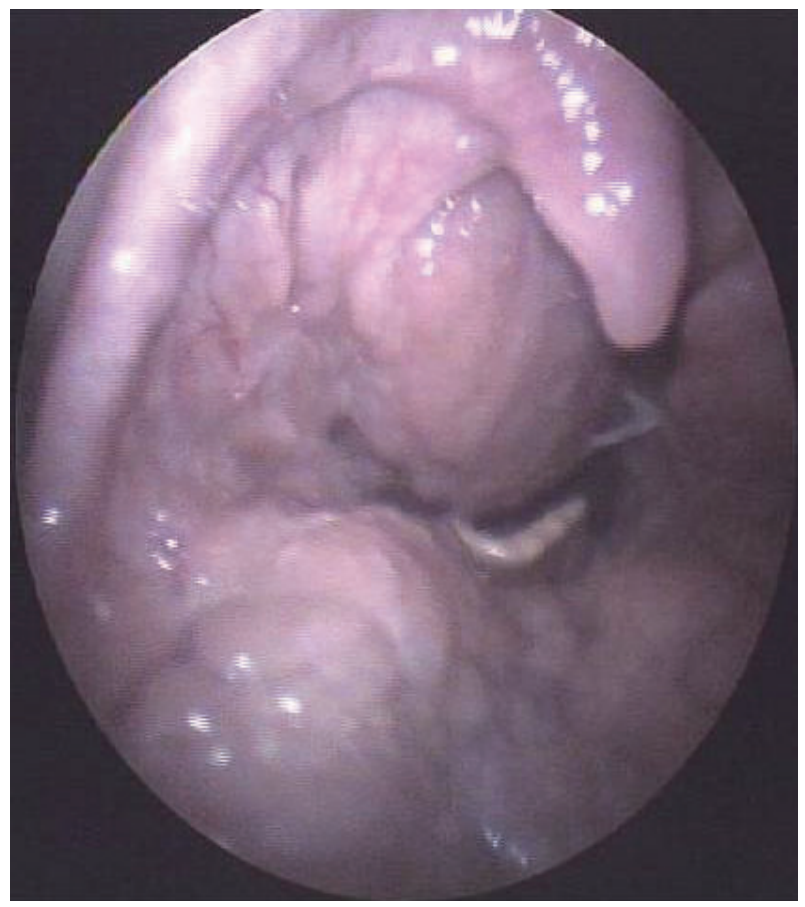

Fig. 1. Initial finding of oropharynx: retropharyngeal mass narrowed the oropharyngeal space.
퓨터단층촬영 $(\mathrm{CT})$ 에서 우측 후인두 공간에 직경 $4.6 \mathrm{~cm}$ 크 기로 전반적으로 둥근 형태에 경계가 분명하고 내부가 균일 하게 저음영으로 보이는 낭종성 병변이 관찰되었으며 병변 주위의 조영 정도는 크지 않았다. 그러나 일부 CT 영상에서 는 병변의 형태가 불규칙한 소견을 보이고 있어 후인두 농양 의 가능성도 배제할 수 없었다(Fig. 2). 진단 목적으로 병변 위에 흡입술을 시행하여 $5 \mathrm{cc}$ 정도의 점성이 높은 짙은 황갈 색 액체를 흡입하였으며, 세균 배양검사에서는 특별한 소견 은 나타나지 않았다. 입원 후 정맥을 통해 3일간 항생제를 투 여하고 대증 치료를 병행하여 발열과 인후통은 호전되었으 나, 융기된 병변으로 인한 기도 폐색 소견의 변화가 없어 전신 마취 하에 경 구강 접근법을 이용한 수술을 시행하였다. 병변 표면 점막에 종절개를 시행하고 점막 하층과 상괄약근(superior constrictor muscle), 협인두근막(buccopharyngeal fascia)을 절개하여 연부 조직을 박리하면서 낭종의 외벽을 확인 할 수 있었다(Fig. 3A). 낭종은 주변 조직과의 유착 없이 후인 두 공간에 위치하고 있어, 큰 어려움 없이 박리하여 en bloc 절제가 가능하였고 낭종 주변으로 누공의 형성이나 침윤 소 견은 관찰되지 않았다. 수술 도중 신경이나 혈관의 노출은 없었으며, 수술 시야에서의 다량 출혈 소견도 보이지 않았다. 낭종 제거 후 남겨진 협인두근막 외측의 주머니 모양의 공간 은 30도 rigid endoscope을 이용하여 육안으로 남아 있는 병 변이 없음을 확인하였다(Fig. 3B). 병리조직검사에서 낭종의 외벽은 중층평편상피로, 내벽은 섬모원주상피로 이루어져 있으며 상피 하 조직 일부에서 림프조직이 관찰되었으며 평활 근이나 연골 조직, 배상 세포는 확인되지 않았다(Fig. 4). 수 술 후 3주까지는 수술 부위 점막의 종창 소견이 관찰되었으며, 수술 후 15 개월까지 외래에서 추적 관찰한 결과 합병증이나
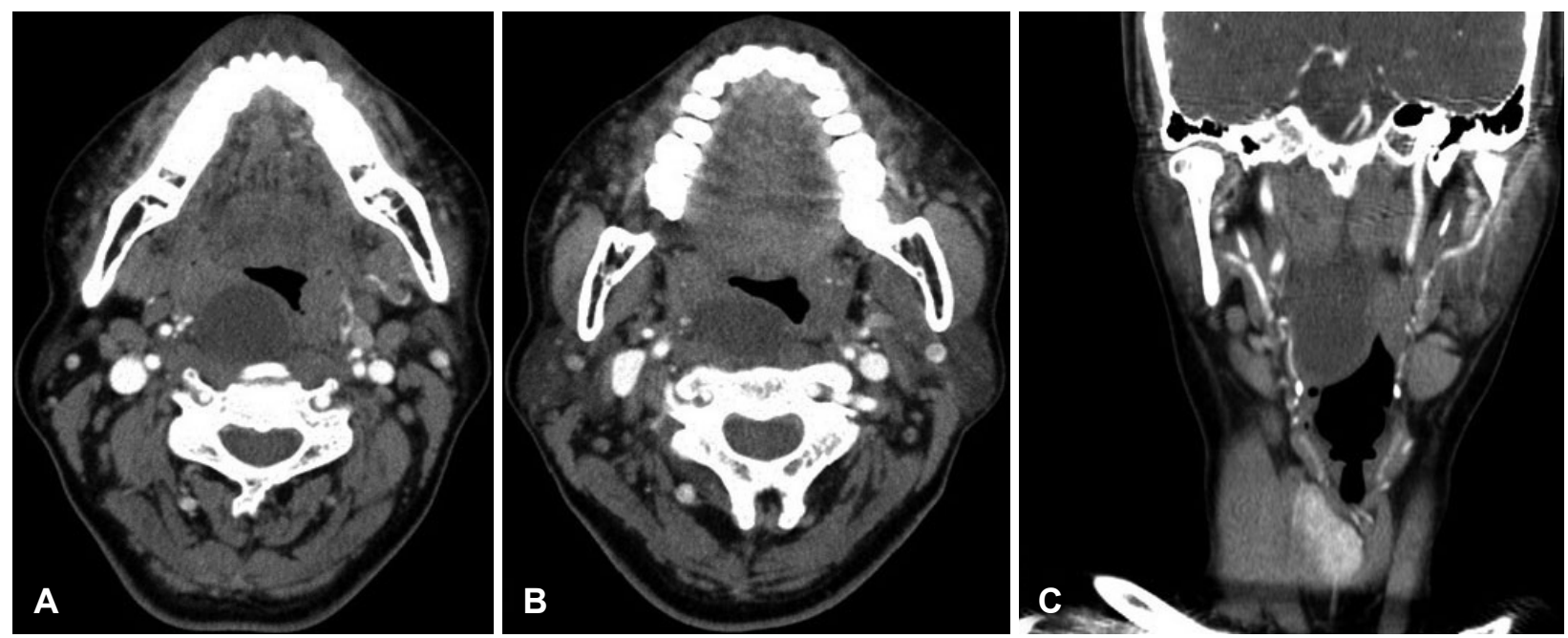

Fig. 2. Axial (A and $B$ ) and coronal $(C)$ images of neck $C T$ showed non-enhancing round mass in right retropharynx. The mass was distinguishable from the adjacent soft tissue. Meanwhile, some CT images showed irregular shaped margin (B). 
Fig. 3. Intra operative finding: the surface of the cystic mass (white arrow) was identified after vertical incision through pharyngeal mucosa, superior constrictor muscle and buccopharyngeal fascia (A). Retropharyngeal space showed normal objective finding after dissecting the mass (B).
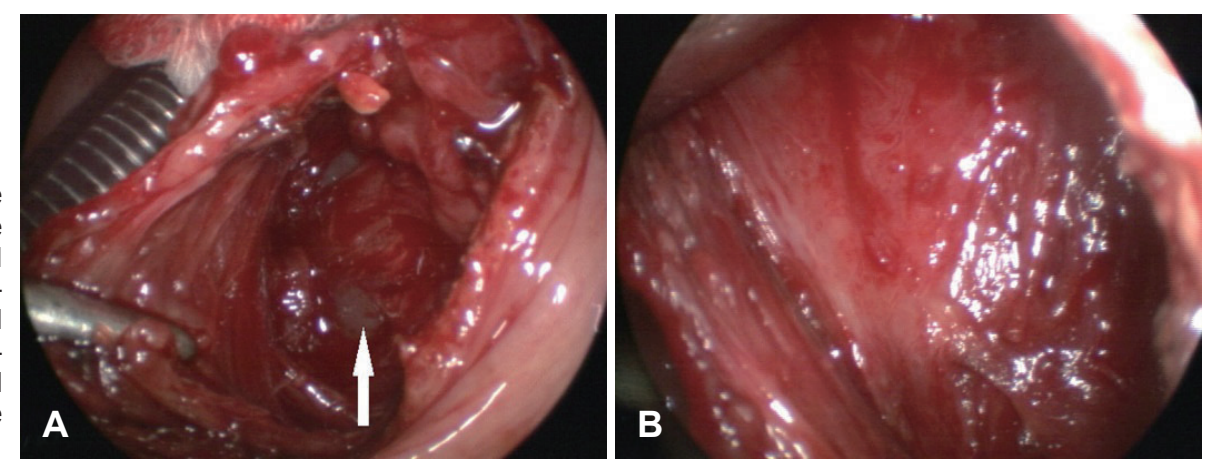

Fig. 4. Pathologic findings with hematoxylin and eosin staining $(A, \times 40)$ $(B, \times 200)$ : the outer surface was composed with stratified squamous epithelium, while the inner surface was comprised of the pseudostratified ciliated columnar epithelium. Lymphocytic infiltration was also seen through the stromal tissue.

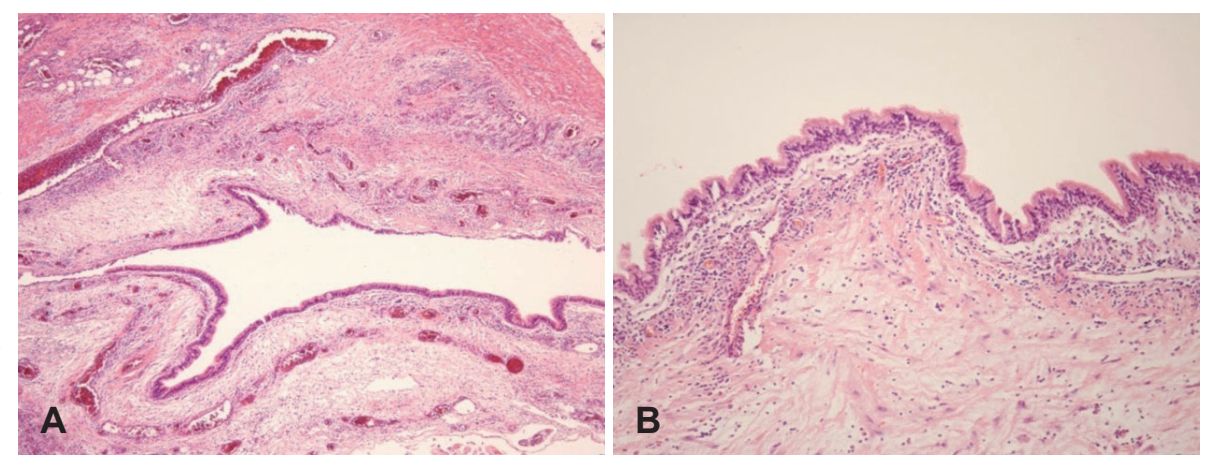

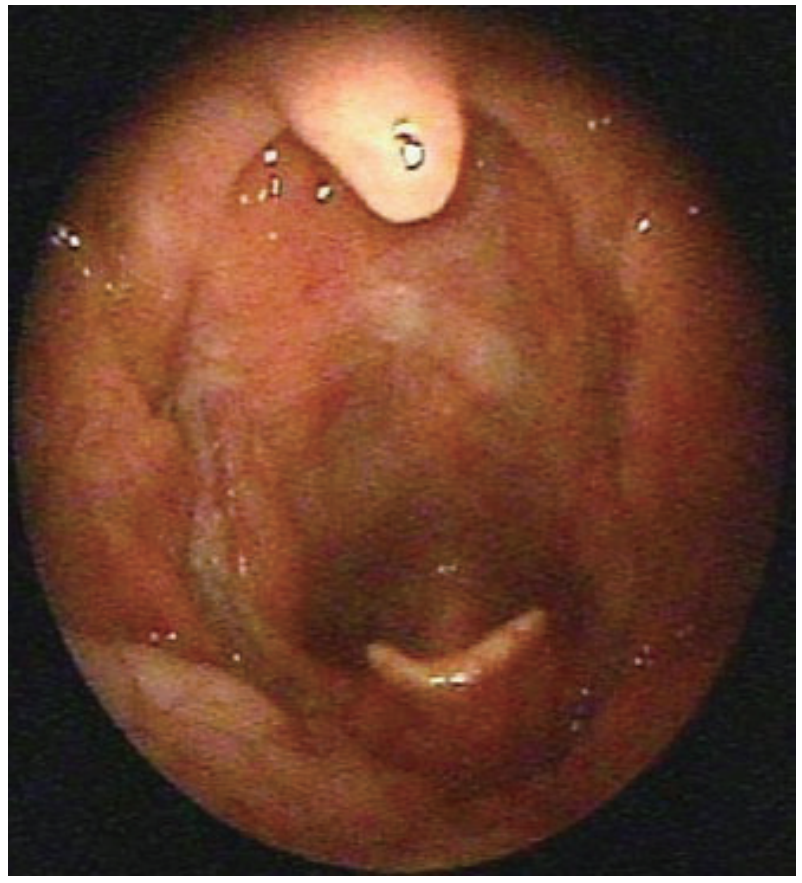

Fig. 5. Postoperative finding 15 months after surgery. It showed absence of any complication or recurrence.

재발의 징후는 보이지 않았다(Fig. 5).

\section{고 찰}

새성기관(branchial apparatus)은 태생기 2주경에 발생하
는 외배엽성의 새열(ectodermal cleft)과 내배엽성의 새낭(endodermal pouch)으로 둘러 쌓인 6쌍의 중배엽성 새궁(mesodermal branchial arch)으로 구성되어 있다. 새성기관은 태생기 4주경에 두 쌍의 새궁이 퇴화하며, 태생 6 주경에 제2 새궁이 제 2, 3, 4 새열을 덮고 심외막 능선(epicardial ridge)까 지 증식하여 내려가 융합하여 경부동(cervical sinus)을 형성 한다. 경부동은 발생의 과정에서 소실되는데, 이 과정에서 제 1,2 새낭의 배측에서 함요(recess)가 만들어져 중이와 이관으 로 분화되며, 제 2 새낭의 복측에는 림프구들이 모여 구개 편 도를 형성한다. 제 3 새낭은 흥선과 하측 부갑상선의 기원이 된다. 새기형은 이러한 새성기관의 분화 과정에서 불완전한 폐쇄에 의해 발생한다고 알려져 있다.,5) 새기형은 낭종이나 누공, 동의 형태를 보일 수 있으며, 외이도의 주변으로 주행 하는 제 1 새기형과 주로 경동맥 삼각에 위치하는 제 2 새기형, 제2 새기형과 유사한 경로를 보이나 상후두신경의 내측 분지 상방에서 갑상설골막을 뚫고 이상와(pyriform sinus)로 개구 하는 제 3 새기형, 이상와의 첨단에서 시작하여 경부로 올라 와 설하신경의 상부를 돌아 내려가 흥쇄유돌근으로 이어지 며 갑상선 주위 공간과 연관성을 보이는 경우도 있는 제4 새 기형으로 분류된다. 제 2 새기형은 새기형 중 $90 \%$ 이상을 차 지하는 가장 흔한 형태로, ${ }^{7)}$ 이는 제 2 새궁이 발생과정에서 가 장 오랜 기간 동안 깊숙하게 존재하기 때문인 것으로 생각된 다. ${ }^{8)}$ 제2 새기형의 누공로는 흉쇄유돌근 전하방에서 시작되 어 흥쇄유돌근과 경동맥초 사이 공간을 따라 설골 부위까지 
올라간 후 내측으로 들어가 구개편도와까지 이어진다. ${ }^{6,9)}$ 전형 적인 제2 새기형은 보통 부드럽고 둥근 종괴나 누공의 형태 로 흥쇄유돌근의 전방 경계에 위치하며 상기도 감염 시 크기 가 증가할 수 있으며, 편도염의 잦은 재발에도 관련 있다고 알려져 있다. ${ }^{10)}$

하지만 새궁이 심외막 능선과 융합에 실패하여 새기형이 생길 경우, 새열의 내측벽이 파괴되지 않고 유지되면서 누공 의 형성 없이 내배엽과 외배엽이 혼재된 형태의 구인두의 낭 종으로 나타날 수 있다. ${ }^{11)}$ 낭종 형태의 새기형은 상피 하 조직 에 배중심(germinal center)을 포함한 림프 조직을 포함하고 있으므로, 림프절의 낭성 변화를 통해 발생한다는 주장도 있 다. ${ }^{12)}$ 실제 후인두의 낭종에서 제2 새기형이 진단되는 경우는 매우 드물며, 국내에서는 2세 여아에서 주관적인 증상 없이 좌 측 편도 후방에서 우연히 발견되어 수술적으로 제거한 1 예 ${ }^{2)}$ 와 2개월 전부터 서서히 발생한 간헐적인 목의 이물감과 코 골이를 주소로 내원한 14세 남아에서 구강 내 절개를 통해 제거되어 진단된 $1{ }^{1}{ }^{3)}$ 가 보고되었다. Saussez 등ํ은 내원 1년 전부터 진행된 코골이를 호소한 54세 남자 환자에서 후인두 의 낭종을 확인하여 구강 내 절개를 통해 제거하고 제2 새기 형으로 진단하여 보고하였다. 성인 환자에서는 낭종 주변의 반복되는 감염과 과거의 절개 배농이나 불완전한 수술적 치 료로 인한 유착으로 제 2 새기형이 초기에 측인두 농양으로 진단될 수 있다는 보고가 있으나, ${ }^{13)}$ 제2 새기형에서 본 증례 처럼 병변 부위의 반복된 감염이나 수술적 치료의 과거력이 없으면서 급성으로 진행되는 삼킴 곤란과 통증, 호흡 곤란 증상을 보인 경우는 문헌 고찰을 통해 확인했을 때 보고된 바가 없었다. 본 증례에서는 인후통과 호흡 및 삼킴 곤란 등 의 임상 증상의 발현 양상과 혈액 검사 소견을 보았을 때 후 인두 농양의 가능성을 배제할 수 없었으나, 컴퓨터단층촬영 검사에서 주변 조직과 잘 경계 지어지며 내부가 균질하게 조 영되지 않는 둥근 형태의 병변을 보이고 있어 낭종성 병변을 의심하였다. 또한 낭종의 위치가 구인두와 하인두에 걸쳐 있 고 후인두 점막에서 깊지 않아, 충분히 시야를 확보하면서도 경부 접근법에 비해 합병증 발생의 가능성이 낮은 구강 내 접근법을 이용하여 수술적 절제를 시행하였다. 누공을 동반 하지 않은 후인두 측벽의 낭종에 대해 제 2 새기형으로 진단 하기에 앞서, 낭종의 모양과 위치로 판단했을 때 기관지 낭종 이나 ${ }^{14)}$ 후인두 점막하층에 존재하는 림프 조직의 낭성 변화의 가능성을 고려해야 한다. 본 증례는 수술 후 조직병리검사에 서 중층평편상피로 이루어진 낭종의 외벽과 섬모원주상피로 이루어진 내벽을 확인할 수 있었다. 상피 하 조직에서 림프 조직이 관찰되었으며 평활근이나 연골, 배상 세포는 확인되 지 않아, 기관지 낭종보다는 새기형의 소견에 합당한 것으로
판단하였다. 낭성 변화를 보인 림프 조직과 새기형의 감별을 위해 추가적으로 cytokeratin 발현에 대한 면역 화학 염색 검사를 시행하는 것이 도움이 될 수 있으나, ${ }^{15)}$ 본 증례에서는 시행되지 않았다. 다만 제2 새기형은 흉쇄유돌근의 전면 하부 $1 / 3$ 지점에서부터 경동맥초를 따라 상행하여 뇌, 외경동맥의 사이를 지나 설골 상부에서 설하신경 주위를 돌아 구개편도 와에 이르는 경로 중에서 어디에서나 발생할 수 있으며, 문헌 고찰에서 본 증례의 영상학적 소견과 병리조직학적 검사가 앞 서 후인두에서 발생하여 제 2 새기형으로 진단했던 낭종의 증 례들과 ${ }^{1-3)}$ 유사하므로 제2 새기형의 가능성이 가장 높다고 판 단하였다. 또한 Proctor ${ }^{16)}$ 의 새기형에 대한 분류 기준으로 판 단했을 때, 본 증례는 제2 새기형의 type 4로 진단하였다.

모든 새기형은 완전한 수술적 절제을 치료 원칙으로 하며," 경화요법과 같은 비수술적인 치료 방법은 효과가 입증되지 않았다. ${ }^{6}$ 본 증례와 같은 양상의 새기형에서 초기 임상 증상 만으로 편도 주위 농양이나 후인두 농양으로 진단하여 항생 제 투여와 함께 단순히 흡인이나 절개 배농만 시행하는 경우 에는, 정확한 진단과 치료가 이루어지지 못하여 재발의 원인 이 될 수 있으므로 주의가 필요하겠다.

\section{REFERENCES}

1) Saussez S, De Maesschalk T, Mahillon V, Filleul O, Louryan S. Second branchial cyst in the parapharyngealspace: a case report. Auris Nasus Larynx 2009;36(3):376-9.

2) Choo MJ, Kim YJ, Jin HR. A case of second branchial cleft cyst with oropharyngeal presentation. J Korean Med Sci 2002;17(4): 564-5.

3) Moon SI, Han JW, Kim JH, Yoon SW. A case of oropharyngeal branchial cyst. Korean J Otolaryngol-Head Neck Surg 2001;44(6): 678-80.

4) Panchbhai AS, Choudhary MS. Branchial cleft cyst at an unusual location: a rare case with a brief review. Dentomaxillofac Radiol 2012;41(8):696-702.

5) Kim HM, Lee DC, Park JW, Kim MS. A case of bilateral second branchial cleft anomaly. Korean J Otorhinolaryngol-Head Neck Surg 2010;53(11):723-5.

6) Chandler JR, Mitchell B. Branchial cleft cysts, sinuses, and fistulas. Otolaryngol Clin North Am 1981;14(1):175-86.

7) Doi O, Hutson JM, Myers NA, McKelvie PA. Branchial remnants: a review of 58 cases. J Pediatr Surg 1988;23(9):789-92.

8) Drumm AJ, Chow JM. Congenital neck masses. Am Fam Physician 1989;39(1):159-63.

9) Tae K, Jeong SW, Lee EJ, Lee SH, Kim KR, Park CW, et al. A clinical study of branchial anomaly. Korean J Otolaryngol-Head Neck Surg 2002;45(10):998-1003.

10) Dallan I, Seccia V, Bruschini L, Ciancia E, Franceschini SS. Parapharyngeal cyst: considerations on embryology, clinical evaluation, and surgical management. J Craniofac Surg 2008;19(6): 1487-90.

11) Thaler ER, Tom LW, Handler SD. Second branchial cleft anomalies presenting as pharyngeal masses. Otolaryngol Head Neck Surg 1993;109(5):941-4.

12) Huang RY, Damrose EJ, Alavi S, Maceri DR, Shapiro NL. Third branchial cleft anomaly presenting as a retropharyngeal abscess. 
Int J Pediatr Otorhinolaryngol 2000;54(2-3):167-72.

13) Paczona R, Jóri J, Czigner J. Pharyngeal localizations of branchial cysts. Eur Arch Otorhinolaryngol 1998;255(7):379-81.

14) Lee JY, Lee JY, Jin SM, Lee SH. A case of bronchogenic cyst in the retropharyngeal space. Korean J Otorhinolaryngol-Head Neck Surg 2013;56(1):41-4.
15) Flanagan PM, Roland NJ, Jones AS. Cervical node metastases presenting with features of branchial cysts. J Laryngol Otol 1994; 108(12):1068-71.

16) Proctor B. Lateral vestigial cysts and fistulas of the neck. Laryngoscope 1955;65(6):355-401. 